\title{
Workplace Spirituality and the Motivational Impact of Meaningful Work: An Experimental Study
}

\author{
Mumphord Kendall \\ Indiana Wesleyan University
}

The question of whether the Spiritual Self affects workplace behavior and performance, not just job attitudes, bears directly on the business case for workplace spirituality. This study seeks to extend prior research by examining the relationship between meaningful work, a component of workplace spirituality, and worker motivation. The study pioneered an experimental method focused on measurable performance outcomes. Temporal order was controlled, allowing causality to be established. The study demonstrates workers who connect a self-transcendent purpose to otherwise mundane tasks are both more productive and satisfied. The empirical evidence for workplace spirituality is compelling and points towards future research directions.

\section{WORKPLACE SPIRITUALITY AND THE MOTIVATIONAL IMPACT OF MEANING}

William James (1890) described a mechanism he observed at work in human beings which governed perceptions about every facet of life, including work. If it were altered, a person would become alienatus a se, or alienated from themselves. James labeled this mechanism the Spiritual Self:

It is what welcomes or rejects. It presides over the perception of sensations, and by giving or withholding its assent it influences the movements they tend to arouse. It is the home of interest, - not the pleasant or the painful, not even pleasure or pain, as such, but that within us to which pleasure and pain, the pleasant and the painful, speak. It is the source of effort and attention, and the place from which appear to emanate the fiats of the will. (p. 297-298)

Today, spirituality is recognized as a powerful source of identity. The open expression of spirituality can be found in popular television series, movies, and books. It is a source of basic life principles and assumptions about reality, and is a major determinant of behavior (Mitroff \& Denton, 1999b; Guillory, 2000). Spirituality therefore becomes an essential subject for organizational study. To fail to acknowledge its presence and significance to organizational life may be naïve.

Over the past 25 years, workplace spirituality has become an extremely popular topic, remarkable to the point its growth rate has itself become a focus of discussion and study (McKee, 2003). It has emerged as a significant scholarly and business movement (Conlin, 1999; Garcia-Zamor, 2003). Workplace spirituality has been christened a new business paradigm (Ashmos \& Duchon, 2000; Laabs, 1995), and described as "the most significant trend in management since the human potential movement of the 50s" 
(Aburdene, 2005, p. 68). The popularity of workplace spirituality has, in turn, compelled a scholarly response (McKee, 2003). Many organizational scientists feel the subject cannot be ignored, even if only to dispel inaccuracies (Duchon \& Plowman, 2005; Leigh, 1997; Rego \& Cunha, 2008).

However, workplace spirituality represents a considerable research problem. Even the word spirituality is in many ways ineffable. While workplace spirituality can be connected to numerous more developed concepts in the organizational literature, research in the field is still considered young and fragmented (Sheep, 2006). Many claims have been made about the positive benefits of workplace spirituality to workers and their employers. However, those claims are often based on anecdotal evidence or inductive logic which can be easily challenged. The scarcity of empirical evidence is a frequent subject of discussion among scholars in the field (Gotsis \& Kortezi, 2008; Lips-Wiersma \& Morris, 2009; Michaelson, 2005; Rego \& Cunha, 2008; Van Tonder \& Ramdass, 2009).

One of the most frequent claims made is that workplace spirituality leads to productive worker behavior that improves organizational performance and creates a competitive advantage. However, this basic assertion is one of the least-supported empirically (Gotsis \& Kortezi, 2008; Michaelson, 2005; Poole, 2009; Van Tonder \& Ramdass, 2009). While research in parallel fields has repeatedly shown relationships between the perceived significance of work tasks and worker attitudes (Hackman \& Oldham, 1980; Bono \& Judge, 2003), as a rule these studies have not explored the impact of selftranscendent or spiritual values. In addition, to date no workplace spirituality studies have been able to clearly demonstrate causality (Poole, 2009). This is critical, as the question of whether spirituality in the workplace leads to productive behavior and performance, not just relates to job attitudes, directly addresses the business case for workplace spirituality.

This study therefore seeks to build on prior research in related fields and to fill a key research gap by examining the relationship between meaningful work, a commonly-espoused component of the concept of workplace spirituality, and worker motivation. As a building block for future research projects, the study first sought to innovate and pilot an experimental method that could address causality. However, using the method developed, the study was then able to successfully demonstrate workers who connect a selftranscendent purpose to their tasks are both more productive and satisfied.

\section{THEORETICAL BACKGROUND AND HYPOTHESES}

Workplace spirituality first began to appear in scientific circles in the early 1990s (Pawar, 2009a). Research is still at an early stage, however, and is developing in many different directions simultaneously (Sheep, 2006; Pawar, 2009b). These include qualitative explorations of spiritually-supportive organizations (Jurkiewicz \& Giaclone, 2004; Pfeffer, 2003; Marques, 2008), development of theory (Kinjerski \& Skrypneck, 2004), measurement instruments (Ashmos \& Duchon, 2000; Moore \& Casper, 2006; Sheep, 2006), practical facilitation of spirituality in work settings (Marques et al., 2005; Mirvis, 1997; Pawar, 2009b), and more recently, empirical investigation of attitudinal and behavioral outcomes (Duchon \& Plowman, 2005; Kolodinsky, Giacalone, \& Jurkiewicz, 2008; Rego \& Cunha, 2008; Scroggins, 2008).

From the beginning, scholars discoursed at length on the lack of definitional clarity regarding the nature of spirituality in the workplace (Cavanagh, 1999; Marques, Dhiman, \& King, 2005; Neal, 1997; Rego \& Cunha, 2008; Tischler, Biberman, \& Altman, 2007; van Tonder \& Ramdass, 2009). Workplace spirituality is a highly abstract, complex, multifaceted, subjective, and personal subject (Neal, 1997; Marques, 2005). It can be viewed from many perspectives and at several different levels. The boundaries of workplace spirituality are unclear, making it difficult to compare results from different studies (GarciaZamor, 2003; Gotsis \& Kortezi, 2008). Research has been criticized for failing to both properly integrate theory from related fields and to distinguish itself from similar concepts (Giacalone \& Jurkiewicz: 2003).

The word spirit is derived from the Latin words spiritus, which means breath. It is regarded as a fundamental life force carried by all human beings (Gracia-Zamor, 2003; Neal, 1997). Spirit can be treated as a noun or a verb. Spirituality, however, is always action-oriented (Dale, 1991). If spirit is an "inner source of energy" (Dehler \& Welsh, 2003, p. 114), then spirituality is "an outward expression of 
that force" (p. 114). Spirit is a construct, something abstract and unobservable like motivation or satisfaction, while spirituality is a concept, as it is easily observable in behavior.

Spirituality is frequently defined as either an inner journey or a search for higher meaning in life (Fry, 2003; Neck \& Milliman, 1994; Mitroff, 2003). It is concerned with transcendent meaning, which involves larger interests beyond the self, rather than immanent meaning, which is a mere concern for practical, ordinary, or ego needs (Ashar \& Lane-Maher, 2004). In psychology, spirituality is defined in terms of feelings, thoughts, and behaviors that stem from a desire to connect with a higher power or purpose (Sheep, 2006). It is important to carefully distinguish spirituality from religion. Spirituality is a broader and more inclusive term than religion. The two are compatible, but they are not identical, and do not necessarily even co-exist (Cavanagh, 1999; Garcia-Zamor, 2003; Van Tonder \& Ramdass, 2009).

Spirituality is a-contextual (Dale, 1991). Workplace spirituality, however, is contextualized. It refers to spiritual expression and experiences in a work setting (Sheep, 2006; Pawar, 2009b). Spirituality is an individual-level experience and an expression of a person's sense of self (Chalofsky, 2003a; Pawar, 2009b). Spirituality in the workplace, however, can be defined at multiple levels (Moore \& Casper, 2006; Pawar, 2009b). For instance, at the individual level, it may involve integrating personal values with work tasks (Kolodinsky et al., 2008). At the work unit level, it may have to do with culture. At higher organizational levels, it could involve workplace policies, values, or climate. The question becomes whether the work environment is supportive of individual-level spiritual values and free expression (Garcia-Zamor, 2003; Kolodinsky et al., 2008; Pawar, 2009b).

The definitional disorder found between scholarly writings on workplace spirituality results from the diversity of perspectives and approaches to the subject. Despite the myriad of perspectives, however, common themes have begun to emerge. Regularly-appearing themes include inner life, transcendence of self, holism and harmony, self-actualization, community, meaningful work, and a sense of connection. A fuller exploration of the numerous definitions of workplace spirituality, including their philosophical and often profound underpinnings, is beyond the scope of this study, but is readily available elsewhere (Ashmos \& Duchon, 2000; Ashforth \& Pratt, 2003; Duchon \& Plowman, 2005; Gotsis \& Kortezi, 2008; Marques, 2008; Marques et al., 2005; Milliman, Czaplewski, \& Ferguson, 2003).

After one such review, Ashmos and Duchon (2000) defined workplace spirituality as "the recognition that employees have an inner life that nourishes and is nourished by meaningful work that takes place in the context of community" (p. 137). This succinct definition captures the most prevalent research themes, and is among the most established in the field (Duchon \& Plowman, 2005; Gotsis \& Kortezi, 2008). In particular, it is frequently referenced in quantitative research studies (Dehler \& Welsh, 2003; Kinjerski \& Skrypnek, 2006; Milliman et al., 2003). It emphasizes the effect of meaningful work, a construct that bridges workplace spirituality to other fields, and is basis of one of the measurement instruments used in this study. For these reasons, Ashmos and Duchon's (2000) definition of workplace spirituality has been gratefully adopted.

\section{Research Gaps}

Even though empirical research is scarce, many scholarly works still contain implicit or explicit hypotheses about workplace spirituality's ability to affect improved motivation, organizational performance, or various job attitudes (Dehler \& Welsh, 2003). Few of these theories have been formally tested (Rego \& Cunha, 2008; Van Tonder \& Ramdass, 2009). Some of these claims are based on parallel studies in related disciplines. Others are based upon inductive logic. A few rely on merely anecdotal evidence (Chalofsky,2003a; Gotsis \& Kortezi, 2008; Koldinsky et al., 2007; Markow \& Klenke, 2005; Neal \& Biberman, 2003). Workplace spirituality has been repeatedly criticized for having an unscientific approach (Duchon \& Plowman, 2005; Tischler, Biberman, \& Altman, 2007).

The full scope of claims made about workplace spirituality is remarkable. The best supported claims about workplace spirituality involve its relationship to job attitudes. Studies have connected elements of workplace spirituality to improved job satisfaction (Meglino, Ravlin, \& Adkins, 1989; Sparks \& Schenk, 2001; Milliman et al., 2003; Kolodinsky et al., 2008), increased organizational commitment (Milliman et al., 2003; Kolodinsky et al., 2008; Rego \& Cunha, 2008), enhanced leadership effectiveness (Sparks \& 
Schenk, 2001; Fry, Vitucci, \& Cedillo, 2005; Markow \& Klenke, 2005), reduced stress (Csiernik \& Adams, 2002), reduced fear (Mitroff and Denton, 1999b), increased organization-based self-esteem (Milliman et al., 2003), and an improved sense of job fit (Scroggins, 2008).

Perhaps the most frequent claim is workplace spirituality has a positive impact on organizational performance, and therefore, profitability (Guillory, 2000; Marcic, 1997; Marques et al., 2005; Miller, 1992; Neck \& Milliman, 1994; Reder, 1982). However, despite the fact it is one of the most frequent assertions made in the existing literature, whether workplace spirituality has any instrumental effect on productive worker behavior may be among the least supported claims. This is a key gap in the existing research (Chalofsky, 2003a; Giacalone \& Jurkiewicz, 2003; Gotsis \& Kortezi, 2008; Michaelson, 2005; Poole, 2009; Van Tonder \& Ramdass, 2009). A few studies have considered worker performance, but in the end they only measured self-reported perceptions of performance, not actual performance (Giacalone \& Jurkiewicz, 2003; Scroggins, 2008). Establishing a link between self-transcendent meaning in work, performance, and motivation is an acute need (Moore and Casper, 2006).

Another crucial research gap is demonstrated causality. To date, all of the empirical research on workplace spirituality outcomes has relied upon cross-sectional techniques that cannot aid understanding of causation. As noted in one literature review, "my commitment could inspire me to find meaning in my work instead of the other way around, and both might instead correlate because of a prior cause" (Poole, 2009, p. 584). Several researchers self-assessed this as a limitation of their own work (see Rego \& Cunha, 2008; Duchon \& Plowman, 2005; Kolodinsky et al., 2007). Causality assumptions in other areas of organizational science have been a significant issue (Judge, Thoreson, Bono, \& Patton, 2001). The development of a method to establish causality thus became a central goal of this study.

\section{Theoretical Foundations and Hypotheses}

Workplace spirituality researchers may have a "largely untapped research agenda" (Lund Dean, Fornaciari, \& McGee, 2003, p. 381), but there is also substantial overlap with other disciplines which help provide a theoretical foundation. For instance, a number of concepts from the field of organizational behavior are precursors to workplace spirituality theories (Pawar, 2009a; Duchon \& Plowman, 2005). The ideas captured in these organizational science constructs are often nearly identical to elements considered in workplace spirituality, simply using different names (Thompson, 2000). This study seeks to build upon these prior works.

It should be noted the study of motivation in organizations is no more straightforward than the study of spirituality. Motivation can be defined simply as the desire to work hard and do well. It involves direction, energy, and persistence (Mann, 2006). However, the full range of human motivation is overwhelming. Motives can be dynamic, unstable, and insatiable. Several motives may work simultaneously in the same individual. They are subjective, personalized, and often difficult to detect (Fry, 2003). While humans have the ability to override their animal drives, human motives are still frequently irrational (McClelland, 1961). They are often unconscious and may be obscured even from the individual (Gellerman, 1963).

In the 1960s and 1970s, Maslow, Herzberg, McClelland, McGregor, Gellerman, and other scholars made important breakthroughs in work motivation theory. All of these researchers made explicit references to the power of spirituality as a motive. Herzberg, Mausner, and Snyderman (1959/1993) noted primitive workers, as small business owner-operators, were better able to seamlessly integrate aesthetic, religious, and social goals into their work. They suggested this may have resulted in a higher level of motivation. Herzberg is considered the father of the job-enrichment movement. Meaningful work, a commonly cited dimension of workplace spirituality, extends Herzberg's ideas (Duchon \& Plowman, 2005; Chalofsky, 2003b; Helliwell, 2009). McClelland (1961) examined commonalities in beliefs among various religious traditions. He found those faiths which stressed daily communion with the divine in all areas of life, especially at work, possessed a higher than average need for achievement. McGregor (1960) emphasized the importance of value alignment between an organization and its members, allowing the organization to be propelled by people's motivation rather than attempting to redirect individual motives. His theories have been related to the workplace spirituality dimension of holism (Ashforth \& Pratt, 2003). 
Gellerman (1963) was particularly interested in the motivational power of self-identity, which is a major theme in the workplace spirituality literature (Gotsis \& Kortezi, 2008; Millman et. al, 2003; Sheep, 2006).

Even Abraham Maslow's (1943) famous Hierarchy of Needs pointed towards the motivational power of meaningful work. Maslow's (1943) original hierarchy is ubiquitous, and is still taught in business schools around the world. However, far fewer seem to know Maslow later recognized self-actualization alone fails to explain self-sacrificial behavior, causing him to alter his theory (Conley, 2007). It was evident to Maslow (1970) that a higher-order motive was serving to override basic deficiency needs. He therefore revised and expanded his famous hierarchy, placing self-transcendence above self-actualization. Maslow (1971) observed profoundly motivated people were often "devoted to some task, call, vocation, beloved work outside themselves" (p. 291). This is what workplace spirituality scholars now label meaningful work (Chalofsky, 2003a). Maslow (1971) argued to fully describe a human being you must consider their intrinsic values as much as their physiological needs. He therefore placed an instinctual need for self-transcendence on the same continuum as hunger.

This study, however, uses a framework based on a more modern theory of motivation put forward by Shamir (1991). Shamir argued classic motivation theory too often relied on hedonistic "cognitivecalculative processes" (p. 405), while ignoring the impact of values and morality. He noted it has been well-established in the psychological and sociological literature that when someone acts in congruence with their core beliefs and idealized self-image, they feel a sense of satisfaction. This intrinsic reward accrues any time attitudes are expressed or behavior occurs that affirms self-identity, even when there is no social recognition. The reward then serves to reinforce the originating behavior, making it motivated. Human beings are expressive of their attitudes, feelings, and identities. Motivated behavior thus involves more than calculative processes, explaining actions which are not instrumental or are even sacrificial. Research has shown the more behavior reflects a person's most salient identity, the more motivated they will be to pursue it. Someone with a strong spiritual self-image would be powerfully motivated to exhibit behavior which they believe reflects those ideals. This study's operationalization of this theory is shown below as Figure 1.

\section{FIGURE 1 \\ CONCEPTUAL FRAMEWORK}

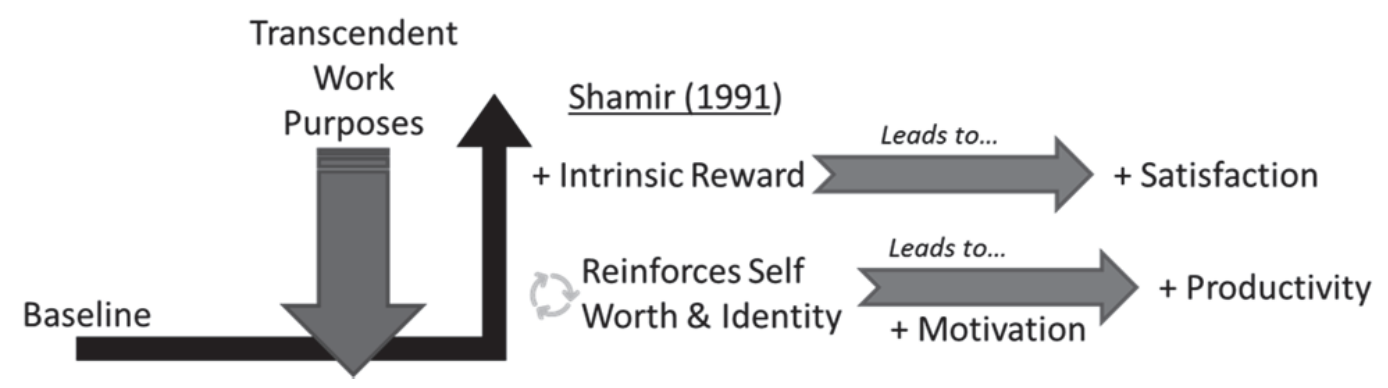

This self-concept-based theory has been further developed through research in transformational leadership and self-concordance (Bono \& Judge, 2003). Shamir's work outlined a process for how leaders could influence followers by enabling value internalization (Shamir, House, \& Arthur, 1993). Later work by Sheldon and Elliot (1999) argued goals that are self-concordant with a worker's own values are naturally reinforcing and lead to well-being. By introducing a connection to transcendent work purposes, a higher level of motivation is accessed. Self-concept-based theory suggests a mechanism which links spiritual identity to work motivation, and thus provides a conceptual framework for this study. Selftranscendent work should support a person's sense of self-worth and idealized self-identity. This accrues an intrinsic reward that leads to satisfaction and then reinforces motivated behavior (Shamir, 1991). This research therefore sought to manipulate the connection to self-transcendent meaning in a work task through an experimental treatment, leading to the study's primary hypothesis. 
Hypothesis 1: There is a difference across experimental groups for productivity and task satisfaction, after controlling for gender and spiritual perspective.

Since spirituality is an individual-level experience (Pawar, 2009b), the psychological underpinnings of spirituality are certainly relevant to the study of workplace spirituality. Spirituality is well recognized as an integral part of human nature in psychology and psychiatry (Benjamin \& Looby, 1998). The conscious self has been conceived as a composition of material, social, and spiritual elements since William James' (1890) seminal work. Today, spirituality is distinguished from the five classic factors of personality. There are over 70 different psychometric instruments available to measure aspects of spirituality (MacDonald, 2000). The concept of workplace spirituality rests in part on the hypothesis that when an individual's spirituality is acknowledged, a unique psychological work climate is created. This climate in turn shapes the work unit through attitudes, values, expressed character, and identities (Duchon \& Plowman, 2005).

One of the most common themes in the workplace spirituality literature is holism. Human beings innately seek to integrate their work with their self-identity. This idea springs from some eighty years of psychoanalytic research. For instance, Carl Jung's (1933) theory of individuation states that people instinctively pursue their true and unique selves in an effort to become whole and distinctive. Maslow (1954) would later assert that connecting to unique self is a prerequisite to achieving self-actualization. Without this sense of connection, a person can never realize their true higher and specific purpose. Since self-actualized individuals tend to be more self-confident and empowered, it has therefore been suggested that by encouraging spiritual development, organizations enable their members to take initiative and become more valued contributors (King \& Nichol, 1999). While this study piloted an experimental approach, perceptions of meaning in work were also measured with a psychometric survey instrument, allowing a more traditional cross-sectional hypothesis to be formed.

Hypothesis 2: There are significant, bivariate relationships between perception of work meaning and the variables: productivity as a proxy for motivation, task satisfaction, and spiritual perspective.

The organizational science construct most frequently associated with workplace spirituality is personorganization fit. Person-organization fit can be defined as the degree of congruence between individual worker values and organizational culture. Research suggests better person-organization fit results in many of the same benefits credited to workplace spirituality, such as improved work attitudes, job satisfaction, commitment, and even organizational performance (Koldinsky et al., 2007). The alignment of personal spiritual values and of preferences for spiritual expression in an organizational setting would allow holism in the workplace. This could be considered one form of person-organization fit (Sheep, 2006). Studies of person-organization fit have found value consensus is the most important variable in explaining work-unit performance (Enz \& Schwenk, 1991). The experiment conducted as part of this research sought to create an artificial work environment congruent with worker values, leading to the study's third and final hypothesis.

Hypothesis 3: The greater the level of connection between work tasks and self-transcendent purpose, the greater the perception of meaningful work.

\section{METHODS}

\section{Sample}

This study drew its participants from a population of adult business-school students at a Midwestern university. There were 92 participants in 10 clusters. To select participants, we used a randomized clustersampling technique. While cluster sampling results in less precision, it is more economical than simple random sampling. It maintains the random assignment necessary to establish causality, and is well suited when the target population falls naturally into predetermined clusters, such as classrooms. From the 
population of classrooms, a list of target classes was randomly selected. The corresponding instructors were then approached for permission to conduct the experiment. If the instructor was unwilling or unable to participate, another class was randomly selected. This process continued until sufficient participants were attained. Classes were randomly assigned to one of the three levels of experimental treatment. This insured the sample groups were as homogeneous as possible, and that any differences between the groups were randomly distributed. A classic R-X-O experimental design was thus created, aiming to maximize internal validity with relative efficiency.

Research using Ashmos and Duchon's (2000) Meaning at Work subscale has previously found effect sizes between groups in excess of 2.5 standard deviations (Milliman et. al, 2003). For this study, a power analysis showed a main effect size as small as one standard deviation could be detected, with a power of .80 and a statistical significance of .95 , using a sample as small as 14 participants for each of the experimental treatment levels. To achieve .90 power, a sample of 17 would be necessary. This study therefore targeted 30 participants for each experimental level, well in excess of the minimum required.

\section{Procedures}

This study utilized a laboratory experimental approach. While the phenomenon being studied, the motivational impact of meaningful work, is not particularly novel, the approach and context are pioneering. As far back as Hackman and Oldman's (1980) research on task satisfaction and job enrichment, researchers have repeatedly shown the positive effects of connecting work to a self-valued purpose. It is the intent of this research to build on these prior studies. However, the impact of a purely self-transcendent purpose is far less understood. Furthermore, virtually all of the studies which have delved into this arena left the issue of causality unresolved (Poole, 2009).

It must be acknowledged that to some, a positivistic perspective and workplace spirituality appear incompatible. This has certainly been argued (Benefiel, 2003). Purist positivism implies human beings are driven solely by their environments (Donaldson, 2005). This sharply contrasts workplace spirituality, which assumes behavior is largely driven by individual values (Ashmos \& Duchon, 2000). Unlike the unquantifiable construct of spirit, however, spirituality is revealed in observable behavior (Dehler \& Welsh, 2003). It could be stated that in general, organizations are complex and dynamic open systems which are not ideal for oversimplified quantitative study. In this study, the experimental setting was tightly controlled against confounding external influences, in the hope the connections between values, meaning, and behavior could be detected. The research design is portrayed in Figure 2.

FIGURE 2

\section{RESEARCH DESIGN SCHEMATIC}

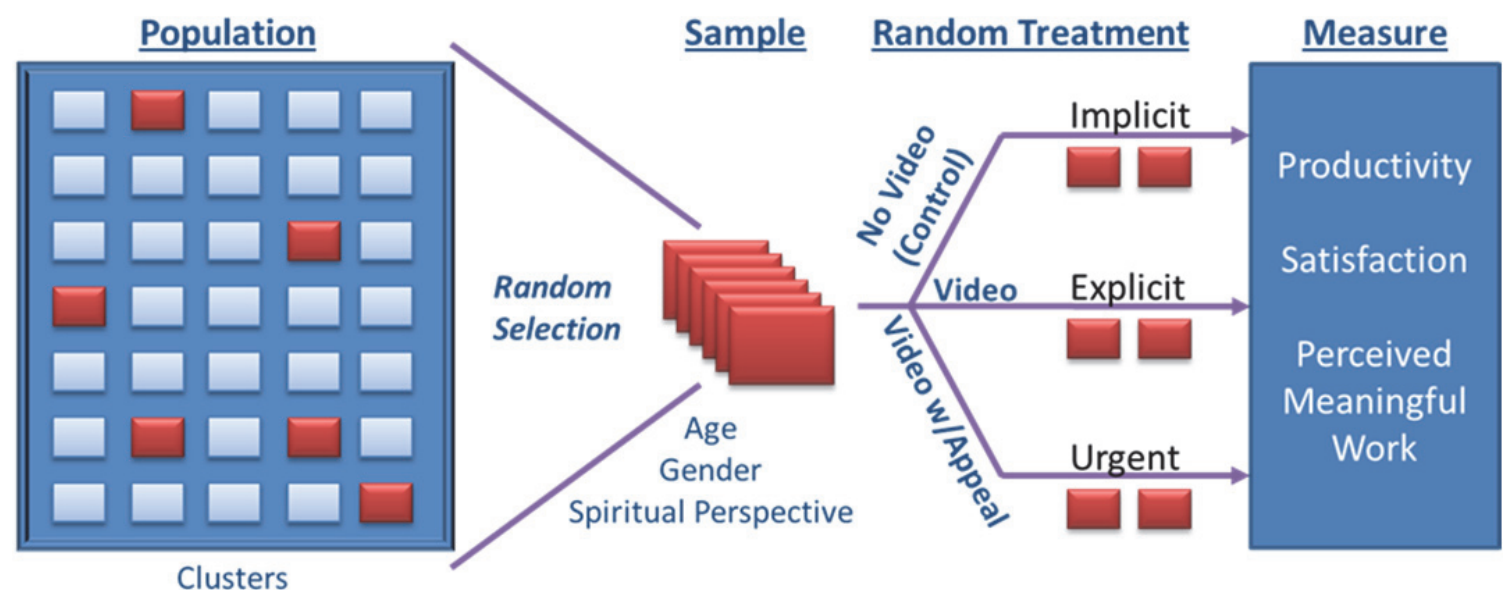


Developing a suitable experimental methodology was no trivial challenge. First a work task had to be identified which was imbued with little or no inherent meaning. From this baseline, the task needed to be of a nature it could then be given self-transcendent meaning through a straightforward experimental treatment. The task had to be simple enough it could reasonably performed by untrained participants, but engaging enough measures of productivity and satisfaction would be worthwhile. One of the central purposes of this study was simply to pilot such a procedure for further development.

The task selected was for participants to clean, evaluate, categorize, and package used prescription eyeglasses. The participant workers removed the eyeglasses from a central collection bin, sprayed them with cleaning fluid, and then polished them dry. They then filled out a short checklist which required them to both evaluate the condition of each set of eyeglasses and to sort them into categories, such as whether they were male or female-styled, sized for an adult or a child, or intended as sun glasses or reading glasses. Once the checklist was complete, the participants individually bagged each pair of eyeglasses, along with its respective checklist, and placed them into special storage boxes. Output was measured over a 45 minute work period as a proxy for level of effort and motivation.

Once randomly selected, sample clusters were then randomly placed into groups. Control groups were asked to begin the cleaning and sorting activity immediately following instruction. Experimental groups, however, were shown a video before the exercise began. This brief video dramatically depicted needy people in impoverished countries receiving the eyeglasses from an international Christian medical ministry organization (see www.youtube.com/watch? $\mathrm{v}=\mathrm{dClxPh} 7 \mathrm{XVBo}$ ). The work activity was thus revealed as an important step in a supply chain delivering eyeglasses to those desperately in need. This connected the work activity to a self-transcendent purpose in an attempt to create meaningful work, as defined in the workplace spirituality literature (Ashmos \& Duchon, 2000).

Following the work period, we asked the participants to complete a short survey. This postexperiment survey had two purposes. The first was to validate the videos had successfully connected a self-transcendent purpose to the work activity. If no relationship was found between the explicitness of the connection made in the videos and the perceptions of work meaning, there would be good reason to question the effectiveness of the videos and the construct validity of the research design. Second, this survey could also be used to study the correlation between perceived meaning in work and several other variables, including spiritual perspective, motivation, and task satisfaction.

\section{Measures}

Both spirituality and motivation have proven difficult to measure (Ashmos \& Duchon, 2000). Spirituality can at least be observed in the form of behavior focused on the spiritual or self-transcendent. Well-tested survey instruments for job satisfaction are readily available. Motivation, however, is not directly observable and must be inferred (Dehler \& Welsh, 2003).

\section{Productivity. Experimental Output / Time}

Fortunately, effort, the dedication and energy to complete a task, is a resultant of motivation and can be measured (Mann, 2006). While motivation is an abstract construct that cannot be easily captured with survey instruments (Ehrlich, 2006; Fry, 2003), effort can be used as an effective surrogate (Terborg, 1976; Mann, 2006; Burroughs et. al., 2011). In this experiment, participants were given a very simple task, and then productivity was used as a proxy for motivation and effort. This formed the study's first dependent variable.

\section{Task Satisfaction}

We chose to use the general job satisfaction factor of Hackman and Oldman's (1975) Job Diagnostic Survey. It is notable Hackman and Oldham (1980) regarded the experienced meaningfulness of work as highly important to the development of internal work motivation. Their survey was originally created to give researchers an effective way to measure the impact of their job redesign efforts. The general satisfaction subscale is "an overall measure of the degree to which an employee is satisfied and happy with their job" (Hackman \& Oldham, 1975, p. 162). It is a simple measure of overall affective response. 
The four questions of the 7-point Likert-type subscale are generic, allowing them to be directed towards the participant's experiences in the artificial work environment. In fact, this survey has been used in similar research before. It is extremely well tested, consistently yielding Cronbach alpha values above 0.78 (Sparks and Schenk, 2001). Task satisfaction was treated as this study's second dependent variable.

\section{Perceived Meaningful Work}

The post-experiment survey included seven questions from the Meaning at Work section of Ashmos and Duchon's (2000) workplace spirituality scale. This instrument was specifically developed for use in studying organizational performance and has been more heavily tested than any other workplacespirituality instrument. Ashmos and Duchon's definition of workplace spirituality is frequently cited in the literature and was adopted for this research. The Meaning at Work question items capture "a sense of what is important, energizing and joyful at work" (p. 139). This 7-point Likert-type subscale assesses dimensions of work that are considered spiritual, not intellectual or physical. It is descriptive of the component of workplace spirituality known as meaningful work. Ashmos and Duchon's initial testing established a Cronbach's alpha value of .86 for this factor.

\section{Level of Connection to Meaningful Work}

The videos allowed the study's key independent variable, the level of connection to meaningful work, to be manipulated. It is conceivable control group participants might have correctly guessed the true purpose of the activity, or have derived some form of intrinsic satisfaction from the challenge. In either case, they may have found the work activity implicitly meaningful. For the experimental groups who saw the video, however the connection to a self-transcendent purpose was explicit. The first experimental clusters were shown a simple version of the video which portrayed participant's work as a step in the distribution of eyeglasses to needy people. However, as this was a pilot procedure, it was initially unclear how intense this treatment message needed to be. Therefore, additional experimental clusters were shown a second version of the video. This version included a direct appeal from the Christian medical ministry, asking participants to support their cause energetically during the 45 minute activity period. This effectively created three levels of the study's independent variable, connection to meaningful work: implicit, explicit, and urgent.

\section{Moderating Variables}

Several variables were measured as potential moderators - baseline spiritual perspective, age and gender. To measure spiritual perspective, ten questions were used from Reed's (1987) Spiritual Perspective Scale. This instrument is designed to measure the degree to which spirituality permeates the respondent's life, including the frequency they participate in spirituality activities. It was originally used in hospitals to examine whether a predisposition towards spirituality had any impact on the effectiveness of various patient care programs. For this study, it was suspected someone who was predisposed towards spirituality might be more strongly affected by a self-transcendent work purpose. Spiritual perspective was therefore used in the study's model as a moderating variable, and assumed to have a continuous distribution. Reed's (1991) testing has shown internal consistency measures above .90 in a variety of environments.

\section{Data Analysis}

Since the model included two continuous dependent variables, a categorical experimental independent treatment variable with three levels, and several covariates, multivariate analysis of covariance was selected as the appropriate statistical technique. Multivariate analysis of covariance (MANCOVA) statistically removes the effects of potential covariates, and then treats multiple dependent variables as a vector. The form of the general linear model that was used to investigate this study's research questions is shown below as Figure 3. 
FIGURE 3

GENERAL LINEAR MODEL FOR THE HYPOTHESIS 1

General Linear Model takes the form:

$\mathbf{Y}=\mathbf{X B}+\mathbf{u}$

Where:

$\mathbf{Y}=$ Vector of dependent variables
$\left[\begin{array}{l}\text { Satisfaction } \\ \text { Productivity }\end{array}\right]$

$\mathbf{X}=$ Design matrix of explanatory variables

$\left[\begin{array}{l}\text { Level of connection to transcendent purpose (Experimental) } \\ \text { Gender (Dichotomous covariate) } \\ \text { Spiritual perspective (Continuous covariate) }\end{array}\right]$

$\mathbf{u}=$ Error term

After the data was collected and tabulated, a graphical, descriptive, and univariate analysis was conducted. There were no obvious errors in the data, but there were some outliers. For example, one participant in the explicit level group completed 53 pairs of eyeglasses in the 45 minute work period, more than three standard deviations above the general average. These data points did appear valid, however, so no action was taken to modify or remove them. We calculated Cronbach's alpha values for all scaled factors: Hackman and Oldham's (1975) Job Diagnostic Survey (.95), Reed's (1987) Spiritual Perspective Scale (.97), and Ashmos and Duchon's (2000) Meaning at Work Subscale (.95).

MANCOVA analysis relies on a number of assumptions. The minutiae of these assumptions and their testing are too laborious to detail here. Independence of observations, random sampling, and independence of the covariates across treatments result were insured by random selection of the experimental groups and by maintaining a methodically-consistent process. The other statistical assumptions were systematically tested without major issues. The distributions of spiritual perspective, task satisfaction, and perceived work meaning all showed statistically significant deviations from the normal curve. There were clear peaks evident in the data. Fortunately, analysis of variance techniques are resistant to violations of the assumption of normality, particularly with larger samples where each group is of similar size, as in this study. A comparison of the study's dependents variables across groups is shown in Table 1.

TABLE 1

COMPARISON OF DEPENDENT VARIABLES ACROSS GROUPS

\begin{tabular}{l|ccc|ccc}
\hline & \multicolumn{3}{|c|}{ Task Satisfaction } & & \multicolumn{3}{l}{ Productivity (units) } \\
\hline Treatment Level & Mean & Median & s.d & Mean & Median & s.d \\
\hline Control Groups & 2.5 & 2.25 & 1.35 & 23.7 & 23.5 & 9.01 \\
Explicit Level Groups & 6.01 & 6.50 & 1.15 & 29.1 & 30.0 & 7.54 \\
Urgent Level Groups & 6.4 & 6.75 & 0.76 & 31.3 & 30.0 & 6.98 \\
\hline
\end{tabular}


MANCOVA also relies on the assumption of homogeneity of covariance matrices. Levene's and Box's tests revealed the variance in task satisfaction was statistically different across experimental groups, $F(2,89)=6.48, p<.005$. The control group participants, who did not see the video, had much wider variation in their reported levels of task satisfaction than the experimental groups. Fortunately, research has shown Hotelling's Trace test statistic is robust against violation of this assumption of MANCOVA when there are a small number of groups and dependent variables. This is particularly true when the groups are of approximately equal size (Hakstian, Roed, \& Lind, 1979), as in this study. Pillai's Trace test statistic was included in the analysis, which has also shown to be robust when the assumptions of multivariate normality or homogeneity of covariance matrices are suspect.

\section{RESULTS}

\section{Descriptive Statistics}

Table 2 summarizes the means, standard deviations and zero-order correlations among the research variables.

TABLE 2

DESCRIPTIVE STATISTICS AND CORRELATIONS ${ }^{\mathrm{a}}$

\begin{tabular}{lccccc}
\hline \multicolumn{1}{c}{ Variable } & Mean & s.d. & $\mathbf{1}$ & $\mathbf{2}$ & $\mathbf{3}$ \\
& & & & & \\
1. Productivity & 27.99 & 8.61 & & & \\
2. Satisfaction & 4.90 & 2.09 & $.38^{* *}$ & & \\
3. Work Meaning & 36.69 & 13.27 & $.39^{* *}$ & $.84^{* *}$ & \\
4. Spiritual Perspective & 5.06 & 0.92 & -.19 & .14 & .20 \\
\hline $\begin{array}{l}\text { a } n=93 \\
* p .05\end{array}$ & & & & & \\
$* * p<.01$ & & & & & \\
& & & & &
\end{tabular}

\section{Tests of Hypotheses}

The results for the first hypothesis of the MANCOVA analysis is shown in Table 3. Based on all four test statistics, including the more robust Pillai's Trace and Hotelling's Trace, the group effects were significant. The hypothesis that there is a difference across experimental groups for productivity and task satisfaction, after adjusting for gender and spiritual perspective, was supported.

TABLE 3

\section{SUMMARY MANCOVA ANALYSIS RESULTS FOR FIRST HYPOTHESIS}

\begin{tabular}{lcccc}
\hline & Value & $\boldsymbol{F}$ & Hypothesis $\boldsymbol{d} \boldsymbol{f}$ & Error $\boldsymbol{d} \boldsymbol{f}$ \\
\hline Pillai's trace & .68 & $21.41^{* *}$ & 4.00 & 166.00 \\
Wilks' lambda & .32 & $31.54^{* *}$ & 4.00 & 164.00 \\
Hotelling's trace & 2.13 & $43.13^{* *}$ & 4.00 & 162.00 \\
Roy's largest root & 2.13 & $88.38^{* *}$ & 2.00 & 83.00 \\
\hline$* \mathrm{p}<.05$ & & & & \\
$* * \mathrm{p}<.01$ & & & &
\end{tabular}

Next, a contrast matrix was built and a univariate ANOVA analysis was conducted. The contrast matrix showed the difference between the control and treatment groups was strongly significant for both dependent variables - productivity and task satisfaction, $p<.01$. The ANOVA analysis, shown in 
Table 4, revealed the independent treatment variable, the level of connection to a self-transcendent purpose, was also statistically significant for both dependent variables, $p<.01$. However, there was relatively little difference between the explicit and urgent level treatment groups for either task satisfaction or productivity. Furthermore, the continuous covariate, spiritual perspective, was significant only for productivity, and gender had no discernible impact on the strength of the model.

TABLE 4

ANOVA SUMMARY TABLE FOR DEPENDENT VARIABLES

\begin{tabular}{|c|c|c|c|c|c|}
\hline Source & Dependent Var & Sum of Squares & $d f$ & Mean Square & $\mathbf{F}$ \\
\hline \multirow{2}{*}{ Corrected Model } & Productivity & 1270.990 & 6 & 211.832 & $3.301 * *$ \\
\hline & Task Sat & 284.562 & 6 & 47.427 & $37.706 * *$ \\
\hline \multirow{2}{*}{ Intercept } & Productivity & 4022.480 & 1 & 4022.480 & $62.686^{* *}$ \\
\hline & Task Sat & 73.885 & 1 & 73.885 & $58.740 * *$ \\
\hline \multirow{2}{*}{ Spiritual Persp } & Productivity & 348.795 & 1 & 348.795 & $5.436^{*}$ \\
\hline & Task Sat & .666 & 1 & .666 & .529 \\
\hline \multirow{2}{*}{ Level Code } & Productivity & 732.236 & 2 & 366.118 & $5.706 * *$ \\
\hline & Job Sat & 220.181 & 2 & 110.091 & $87.525^{* *}$ \\
\hline \multirow{2}{*}{ Gender } & Productivity & 3.663 & 1 & 3.663 & .057 \\
\hline & Task Sat & 3.191 & 1 & 3.191 & 2.537 \\
\hline \multirow{2}{*}{$\begin{array}{l}\text { Level Code * } \\
\text { Gender }\end{array}$} & Productivity & 45.074 & 2 & 22.537 & .351 \\
\hline & Task Sat & .198 & 2 & .099 & .079 \\
\hline \multirow{2}{*}{ Error } & Productivity & 5325.999 & 83 & 64.169 & \\
\hline & Task Sat & 104.399 & 83 & 1.258 & \\
\hline \multirow{2}{*}{ Total } & Productivity & 77101.000 & 90 & & \\
\hline & Task Sat & 2552.313 & 90 & & \\
\hline \multirow{2}{*}{ Corrected Total } & Productivity & 6596.989 & 89 & & \\
\hline & Task Sat & 388.962 & 89 & & \\
\hline
\end{tabular}

This study's second hypothesis involved the nature and degree of the relationship between perceptions of work meaning, as measured by Ashmos and Duchon's (2000) Meaning at Work subscale, and three other variables: productivity as a proxy for motivation, task satisfaction, and spiritual perspective. The bivariate correlation between each pair of variables was calculated. Spearman's Rho statistic was utilized as a non-parametric alternative to the Pearson product-moment correlation coefficient, which relies on the assumption of normality. In all three cases, the Spearman's Rho statistics were statistically significant between perceived meaningful work and each variable, with $p<.05$. As a result, the hypotheses there was a relationship between perceived meaningful work and productivity .33, task satisfaction .88 , or spiritual perspective .37 were all supported. Notably, the correlation between task satisfaction and perceived meaning in work were high enough to be practically indistinct measures.

This study's final research question was whether perceptions of meaningful work varied across the experimental groups. In other words, it was necessary to test whether the work goals conveyed by the experimental treatment sufficiently aligned with worker values to create a sense of meaning. However, this was investigated primarily to help validate the effect created by the experimental treatment could be reasonably categorized as meaningful work, as defined in the workplace spirituality literature. A simple comparison of means across the three experimental levels was conducted, comparing results from Ashmos and Duchon's (2000) Meaning at Work subscale used in the post-experiment survey. Since the assumption of normality had been violated by the perceived meaningful work data, the Mann-Whitney test was used as an alternative non-parametric means test and is shown in Table 5. 


\section{TABLE 5 \\ MANN-WHITNEY TEST OF PERCEIVED MEANINGFUL WORK ACROSS GROUPS}

\begin{tabular}{lccc} 
& Control vs. Explicit & Control vs. Urgent & Explicit vs. Urgent \\
\hline Mann-Whitney U & 31.50 & 16.00 & 416.00 \\
Z & $-6.47^{* *}$ & $-6.43^{* *}$ & -0.49 \\
\hline$* * \mathrm{p}<.01$ & & &
\end{tabular}

The Mann-Whitney test revealed a strong and statistically significant difference in mean perceived meaningful work between the control groups and both the explicit and urgent level groups, with $p<$ .0005. Therefore the hypothesis there was a difference across experimental groups for perceptions of meaningful work was supported. However, the statistical significance of the difference in means between the explicit and urgent groups was .63, well above the critical value of .05 . Therefore, for the two treatment groups, the hypothesis there was no difference between the treatment group with the explicit message and the treatment group with the urgent message for perceptions of meaningful work could not be supported.

\section{DISCUSSION}

The evolution of organizational and management science can be traced from the rudimentary view of organizations as machines towards organizations seen as dynamic, complex organisms that have physical, emotional, intellectual, and even spiritual aspects (Conlin, 1999; Sibbet, 1997). Each step took organizational science towards a more holistic conceptualization. This study had the productivity focus of classic scientific management research (Taylor, 1947), but allowed for participants as multi-faceted individuals whose personal values may have had a significant impact on the outcome. Spirituality has long been recognized in psychology and psychiatry as an integral part of human nature (Benjamin \& Looby, 1998), but has often been neglected in the study of organizations. This is not a matter of introducing spirituality into the workplace, but of simply acknowledging something which is already there (Lips-Wiersma \& Mills, 2002).

This research sought to create a work context in which purpose, efficacy, values, and self-worth could all be found, leading to a sense of calling and meaningful work (Baumeister, 1991). People will display a high level of psychological engagement with their work if they perceive it to be a calling (Markow \& Klenke, 2005). The degree of this engagement is not determined by the nature of the actual work tasks being performed, but rather by the meaning attached to them (Wrzesniewski, McCauley, Rozin, \& Schwartz, 1997). When the experimental groups showed higher productivity and satisfaction, it upheld many of the claims made about meaningful work in the workplace spirituality literature, and validated the motivational potential of self-transcendent meaning. Leaders should take note, as this could be an important lever to energize the knowledge workers and managers who are so critical to modern business success. This study could be reframed as research into spiritual leadership (Fry, Vitucci, \& Cedillo, 2005). It was fortuitous the samples were taken from MBA classes, as the exercise stimulated some very productive post-activity discussion and learning experiences for the participants.

This requires a word of caution, however. Any study of spirituality faces a number of serious dilemmas. This research took a reductionist quantitative approach, which risks trivializing important aspects of a subject central to many people's lives (Benefiel, 2003). In addition, while workplace spirituality offers a pathway for individuals to express their identity and to better integrate their work lives with their values, any instrumental approach to the subject opens the door to exploitation (Sheep, 2006). This study firmly supports the business case for workplace spirituality. Whether this represents a win-win scenario or a dangerous opportunity for businesses to manipulate their workers, is up to organizational leaders. 


\section{Limitations and Future Research Directions}

In order to satisfy this study's research priorities, a number of tradeoffs were necessary. This study used an experimental method to establish temporal order and maximize internal validity. As a result, generalizability is severely limited. The work atmosphere created was highly contrived and could hardly be considered an accurate and full representation of a normal working environment. Furthermore, the sample was carefully selected to represent a critical population of interest, namely professionals, managers, and knowledge workers. This was done, in part, to insure the results would be of the greatest possible value in supporting or refuting the business case for workplace spirituality (Ashar \& LaneMaher, 2004). However, the results of this study can only be considered valid within the strictly defined constraints of the experimental setting and sample. The goal of the experiment was to develop and pilot a workable methodology and to demonstrate a theoretical relationship, not to make generalizable inferences. This goal was accomplished. Researchers and practitioners should merely be cautioned it cannot be asserted with any level of confidence these relationships would hold in other settings or more natural surroundings. More replication with larger, more diverse samples is clearly needed.

Like all quantitative approaches to subjects such as spirituality, this study's methodology was necessarily reductionist (Benefiel, 2003). Definitional and measurement issues have plagued the field of workplace spirituality (Moore \& Casper, 2006). The research relied on measurement instruments which had been previously developed and validated. Productivity was used as a proxy for motivation. While steps were taken to confirm the reliability of these measurement techniques, they are inherently imperfect and open to challenge. In addition, much of the meaning behind survey ratings and productivity results was lost. Participants were not given an opportunity to explain their feelings or behavior. The study demonstrated a mechanism functioned as it was expected, but it cannot provide any new insight into why it did so.

All of the measurements taken during this research were at the individual level. However, during the work activity, participants were allowed to interact with their group. There was an active social dynamic which was observed but not captured. Some participants joked and laughed, while others were quiet and focused. Some groups enthusiastically discussed the organization they were helping with their work, while others openly complained. All of these interactions could have had an impact on results. Unfortunately, social influences were not a part of the study, leaving room for future research.

The limitations and delimitations of this study suggest a number of areas for future research. As stated above, generalizability was sacrificed in order to establish temporal order and to maximize internal validity. The sample thus represents a clear opportunity for future research. To strengthen the business case for workplace spirituality, the results should be replicated across larger, more-divergent segments of the working population. For instance, it would be useful to know if the theoretical mechanism holds true for less educated blue-collar workers. Variations in working conditions, task complexity, and methodology would also serve to enhance generalizability.

A significant delimitation of this study was that it collected no qualitative data. This data could have provided valuable insight, either further supporting or challenging the study's conceptual framework. Future research could take several steps to improve the richness of the data. Open ended questions on the post-experiment survey would allow participants to explain their feelings and behavior. More intense observation, perhaps aided by videotape, would allow for detailed follow-up analysis of important social dynamics. The researchers could even assume a leadership position in the experiment, exercising some degree of control over social interactions. The methodology could easily be restructured for a study of spiritual leadership.

The investigation of moderator variables in the relationship between productivity, satisfaction, and work meaning had mixed and inconclusive results. Gender had no significant impact on the strength of the statistical model. Spiritual perspective data was collected in the post-experiment survey, following the experimental activity and videos. This created an opportunity for biased responses. Furthermore, the sample came from a Christian university, leading to little variation in spiritual perspectives. There is reason to believe each of these variables could be related to productivity and satisfaction outcomes. 
Future researchers may wish to try alternative methods of collecting this information to avoid bias. In addition, efforts should certainly be taken to insure as diverse a sample as possible.

\section{Contributions and Conclusions}

This study piloted a methodology for demonstrating when a self-transcendent meaning was connected to a work task, a higher level of motivation and satisfaction was achieved. The assertion a search for selftranscendent meaning is an inexorable part of the human experience is no longer seriously contested. Nevertheless, it continues to be largely marginalized both in work settings and in organizational scholarship (Duchon \& Plowman, 2005). This research was an attempt to study outcomes of utmost concern to modern businesses, namely motivation, productivity, and task satisfaction, but to do so by addressing an oft-neglected variable: the worker's spirituality. The study was designed to bridge classic productivity research with more holistic modern motivation theory, where an individual's sense of identity and personal values have a significant impact on behavioral outcomes. In the process, many of the claims made in the workplace spirituality literature regarding the impact of meaningful work were upheld.

The case for workplace spirituality could be supported purely as a humanistic priority (Lips-Wiersma $\&$ Morris, 2009). However, with scarce resources, intense competition, and a rapidly changing landscape, businesses cannot risk pursuing new management ideas if there is no demonstrable impact to their proverbial bottom lines. Without credible evidence, practicing managers could readily dismiss workplace spirituality as mere fluff and romantic nonsense (Mitroff, 2003). This research therefore aspired to help support or refute the business case for workplace spirituality through a simple demonstration of its power, or at least to suggest a research methodology where this could be accomplished. Participants who understood they were alleviating human suffering were both more productive and satisfied with their work. Leaders should note none of the usual methods, such as pay or promotion, were used to motivate these workers. They saw no immediate personal benefit, and had no connection to the people they were serving. Their only motivation was the unselfish purpose of the work task itself.

The motivational power of meaningful work runs off an internal generator. It has been described as motivation by "pulling rather than pushing" (Michaelson, 2005, p. 235). Worker's energy is channeled, not impelled, creating a possible win-win scenario for businesses and their employees. Organizations get productive and satisfied workers who in turn have the opportunity for meaningful, fulfilling work lives. It may offer both healing and growth. This study provided some of the first causal evidence of the power of self-transcendent meaning to fuel organizations and their people. However, it did so only under the most limited conditions. While this research cast light on important questions, the scope of work remaining to be done is overwhelming. It is hoped the evidence and methods provided here at least peak curiosity and suggest the subject of workplace spirituality merits further serious scholarly attention. 


\section{REFERENCES}

Aburdene, P. (2005). Megatrends 2010. Charlottesville, VA: Hampton Roads.

Ashar, H., \& Lane-Maher, M. (2004). Success and spirituality in the new business paradigm. Journal of Management Inquiry, 13(3), 249-260.

Ashforth, B. E., \& Pratt, M. G. (2003). Institutionalized spirituality: An oxymoron?. In R. A. Giacalone \& C. L. Jurkiewicz (Eds.), Handbook of workplace spirituality and organizational performance (p. 93-107). Armonk, NY: M. E. Sharpe.

Ashmos, D. P., \& Duchon, D. (2000). Spirituality at work: A conceptualization and measure. Journal of Management Inquiry, 9(2), 134-146.

Aupperle, K. E., Carroll, A. B., \& Hatfield, J. D. (1985). An empirical examination of the relationship between corporate responsibility and profitability. Academy of Management Journal, 28(2), 446463.

Bass, B. M. (1985). Leadership and performance beyond expectations. New York, NY: Free Press.

Baumeister, R. F. (1991). Meanings of life. New York, NY: Guilford Press.

Benefiel, M. (2003). Irreconcilable foes? The discourse of spirituality and the discourse of organizational science. Organization, 10(20), 383-391.

Benjamin, P., \& Looby, J. (1998). Defining the nature of spirituality in the context of Maslow's and Roger's theories. Counseling \& Values, 42(2), 92-101.

Bennis, W. (1999). Old dogs, new tricks. Provo, UT: Executive Excellence.

Bono, J. E., \& Judge, T. A. 2003. Self-concordance at work: Toward understanding the motivational effects of transformational leaders. Academy of Management Journal, 46(5): 554-571.

Burroughs, J. E., Dahl, D. W., Moreau, C. P., Chattopadhyay, A., \& Gorn, G. J. (2011). Facilitating and Rewarding Creativity During New Product Development. Journal of Marketing, 75, 53-67.

Cavanagh, G.F. (1999). Spirituality for managers: Context and critique. Journal of Organizational Change Management, 12(3), 186-199.

Chalofsky, N. (2003a). An emerging construct for meaningful work. Human Resource Development International, 6(1), 69-83.

Chalofsky, N. (2003b). Meaningful work. Training and Development, 57(12), 52-58.

Conley, C. (2007). Peak. San Francisco, CA: Jossey-Bass.

Conlin, M. (1999, November 1). Religion in the workplace. BusinessWeek, (3653), 151-158.

Csiernik, R., \& Adams, D. W. (2002). Spirituality, stress and work. Employee Assistance Quarterly, $18(2), 29$.

Dale, E. S. (1991). Bringing heaven down to earth: A practical spirituality of work. New York, NY: Peter Lang.

Dehler, G. E., \& Welsh, M. A. (1994). Spirituality and organizational transformation: Implications for the new management paradigm. Journal of Managerial Psychology, 9(6), 17-27.

Dehler, G. E., \& Welsh, M. A. (2003). The experience of work: Spirituality and the new workplace. In R. A. Giacalone \& C. L. Jurkiewicz (Eds.), Handbook of workplace spirituality and organizational performance (p. 108-122). Armonk, NY: M. E. Sharpe.

Duchon, D., \& Plowman, D. A. (2005). Nurturing the spirit at work: Impact on work unit performance. The Leadership Quarterly, 16(5), 807-833.

Ehrlich, C. (2006). The EFQM-model and work motivation. Total Quality Management \& Business Excellence, 17(2), 131-141.

Enz, C. A., \& Schwenk, C. R. (1991). The performance edge: Strategic and value dissensus. Employee Responsibilities and Rights Journal, 4(1), 75-85.

Field, A. (2009). Discovering statistics using SPSS ( $3^{\text {rd }}$ ed.). Thousand Oaks, CA: Sage.

Fry, L. W. (2003). Toward a theory of spiritual leadership. The Leadership Quarterly, 14(6), 693-727.

Fry, L. W., Vitucci, S., \& Cedillo, M. (2005). Spiritual leadership and army transformation: Theory, measurement, and establishing a baseline. The Leadership Quarterly, 16(5), 835-862. 
Giacalone, R. A., \& Jurkiewicz, C. L. (2003b). Toward a science of workplace spirituality. In R. A. Giacalone \& C. L. Jurkiewicz (Eds.), Handbook of workplace spirituality and organizational performance (p. 3-28). Armonk, NY: M. E. Sharpe.

Garcia-Zamor, J.C. (2003). Workplace spirituality and organizational performance, Public Administration Review, 63(3), 355-363.

Gellerman, S. W. (1963). Motivation and productivity. New York, NY: Vail-Ballou Press.

Gotsis, G., \& Kortezi, Z. (2008). Philosophical foundations of workplace spirituality: A critical approach. Journal of Business Ethics, 78(4), 575-600.

Guillory, W. A. (2000). Spirituality in the workplace. Salt Lake City, UT: Innovations International.

Hackman, J. R., \& Oldham, G. R. (1975). Development of the Job Diagnostic Survey. Journal of Applied Psychology, 60(2), 159-170.

Hackman, J. R., \& Oldham, G. R. (1980). Work redesign. Reading, MA: Addison-Wesley.

Hakstian, A. R., Roed, J. C., \& Lind, J. C. (1979). Two-sample T-2 procedure and the assumption of homogeneous covariance matrices. Psychological Bulletin, 86, 1255-1263.

Helliwell, T. (2009). Overcoming fear and building trust: Creating healthy organizations. In J. Marques, S. Dhiman \& R. King (Eds.), The workplace and spirituality (p. 129-142). Woodstock, VT: SkyLight Paths.

Herzberg, F., Mausner, B., \& Snyderman, B. B. (1993/1959). The motivation to work. New Brunswick, NJ: Transaction Publishers.

James, W. (1890). The Principles of Psychology (vol. 1). London, England: MacMillan and Company.

Judge, T. A., Thoreson, C. J., Bono, J. E., \& Patton, G. K. (2001). The job-satisfaction job-performance relationship: A qualitative and quantitative review. Psychological Bulletin, 127, 376-407.

Jurkiewicz, C. L., \& Giacalone, R. A. (2004). A values framework for measuring the impact of workplace spirituality on organizational performance. Journal of Business Ethics, 49, 129-142.

King, S., \& Nicol, D. M. (1999). Organizational enhancement through recognition of individual spirituality: Reflections of Jacques and Jung. Journal of Organizational Change Management, 12(3), 234-231.

Kinjerski, V., \& Skrypnek, B. J. (2006). Measuring the intangible: Development of the spirit at work scale. Paper presented at the Academy of Management Proceedings.

Kolodinsky, R., Giacalone, R., \& Jurkiewicz, C. (2008). Workplace values and outcomes: Exploring personal, organizational, and interactive workplace spirituality. Journal of Business Ethics, 81(2), 465-480.

Kuhn, T. S. (1970). The structure of scientific revolutions. IL: University of Chicago Press.

Laabs, J. J. (1995). Balancing spirituality and work. Personnel Journal, 74(9), 60.

Leigh, P. (1997). The new spirit at work. Training \& Development, 51(3), 26.

Lips-Wiersma, M., \& Mills, C. (2002). Coming out of the closet: Negotiating spiritual expression in the workplace. Journal of Managerial Psychology, 17(3), 183-202.

Lips-Wiersma, M., \& Morris, L. (2009). Discriminating between meaningful work and management of meaning. Journal of Business Ethics, 88, 491-511.

Lund Dean, K., Fornaciari, C. J., \& McGee, J. J. (2003). Research in spirituality, religion, and work:

Walking the line between relevance and legitimacy. Journal of Organizational Change Management, 16(4), 378-395.

MacDonald, D. A. (2000). Spirituality: Description, measurement, and relation to the five factor model of personality. Journal of Personality, 68(1), 153-197.

Marcic, D. (1997). Managing with the wisdom of love. San Francisco, CA: Jossey-Bass.

Markow, F., \& Kleke, K. (2005). The effects of personal meaning and calling on organizational commitment. The International Journal of Organizational Analysis, 13(1), 8-27.

Marques, J. (2005). HR's crucial role in the establishment of spirituality in the workplace. The Journal of American Academy of Business, Cambridge, 7(2), 27-31.

Marques, J. (2008). Spiritual performance from an organizational perspective: The Starbucks way. Corporate Governance, 8(3), 248-257. 
Marques, J., Dhiman, S., \& King, R. (2005). Spirituality in the workplace: Developing an integral model and a comprehensive definition. Journal of American Academy of Business, Cambridge, 7(1), 81-91.

Maslow, A. H. (1943). A theory of human motivation. Psychological Review, 50(4), 370-396.

Maslow, A. H. (1970). Religion, values, and peak-experiences. New York, NY: Penguin Group.

Maslow, A. H. (1971). The farther reaches of human nature. New York, NY: Viking Press.

McClelland, D. C. (1961). The achieving society. Princeton, NJ: D. Van Nostrand.

McDonald, M. (1999, May). Shush. The guy in the cubicle is meditating. U.S. News \& World Report, $126(17), 46$.

McGregor, D. (1960). The human side of the enterprise. New York, NY: McGraw-Hill.

McKee, D. (2003). Spirituality and marketing: An overview of the literature. In R. A. Giacalone \& C. L. Jurkiewicz (Eds.), Handbook of workplace spirituality and organizational performance (p. 5775). Armonk, NY: M. E. Sharpe.

Meglino, B. M., Ravlin, E. C., \& Adkins, C. L. (1989). A work values approach to corporate culture: A field test of the value congruence process and its relationship to individual outcomes. Journal of Applied Psychology, 74(3), 424-432.

Michaelson, C. (2005). Meaningful motivation for work motivation theory. Academy of Management Review, 30(2), 228-238.

Miller, W. C. (1992). How do we put our spiritual values to work? In J. Renesch (Ed.), New Traditions in Business (p. 69-80). San Francisco, CA: Berrett-Koehler.

Milliman, J., Czaplewski, A. J., \& Ferguson, J. (2003). Workplace spirituality and employee work attitudes: An exploratory empirical assessment. Journal of Organizational Change Management, 16(4), 426-447.

Mirvis, P. H. (1997). "Soul work" in organizations. Organization Science, 8(2), 193-206.

Mitroff, I. I. (2003). Do not promote religion under the guise of spirituality. Organization, 10(20), $375-$ 382.

Mitroff, I.I., \& Denton, E.A. (1999a). A study of spirituality in the workplace. Sloan Management Review, 40(4), 83-92.

Mitroff, I. I., \& Denton, E. A. (1999b). A spiritual audit of corporate America. San Francisco, CA: Jossey-Bass.

Moore, T. W., \& Casper, W. J. (2006). An examination of proxy measures of workplace spirituality: A profile model of multidimensional constructs. Journal of Leadership \& Organizational Studies, 12(4), 109-118.

Neal, J. A. (1997). Spirituality in management education: A guide to resources. Journal of Management Education, 21(1), 121-139.

Neal, J. (2007). Foreword. Spirituality in the workplace (p. viii-x). Fawnskin, CA: Personhood Press.

Neal, J., \& Biberman, J. (2003). Introduction: The leading edge in research on spirituality and organizations. Journal of Organizational Change Management, 16(4), 363-366.

Neck, C., \& Manz, C. (1992). Thought self-leadership: The influence of self-talk and mental imagery on performance. Journal of Organizational Behavior, 13(7), 681-699.

Neck, C. P., \& Milliman, J. F. (1994). Thought self-leadership: Finding spiritual fulfillment in organizational life. Journal of Managerial Psychology, 9(6), 9-17.

Ohmann, O. A. (1955). "Skyhooks" with special implications for Monday through Friday. Harvard Business Review, 33(3), 33-41.

Oliveira, A. (2004). The place of spirituality in organizational theory. Electronic Journal of Business Ethics and Organization Studies, 9(2), 17-21.

Pawar, B. (2009a). Some of the recent organizational behavior concepts as precursors to workplace spirituality. Journal of Business Ethics, 88, 245-261.

Pawar, B. (2009b). Workplace spirituality facilitation: A comprehensive model. Journal of Business Ethics, 90, 375-386. 
Pfeffer, J. (2003). Business and the spirit: Management practices that sustain values. In R. A. Giacalone \& C. L. Jurkiewicz (Eds.), Handbook of workplace spirituality and organizational performance (p. 29-45). Armonk, NY: M. E. Sharpe.

Poole. E. (2009). Organisational spirituality - A literature review. Journal of Business Ethics, 84, 577588.

Reder, M. W. (1982). Chicago economics: Permanence and change. Journal of Economic Literature, 20, 1-38.

Reed, P.G. (1991). Self-transcendence and mental health in oldest-old adults. Nursing Research, 40, 7-11.

Rego, A., \& Cunha, M. P. (2008). Workplace spirituality and organizational commitment: An empirical study. Journal of Organizational Change Management, 21(1), 53-75.

Rubin, A., \& Babbie, E. (2005). Research methods for social work ( $5^{\text {th }}$ ed.). Belmont, CA: Thomson.

Scroggins, W. A. (2008). Antecedents and outcomes of experienced meaningful work: A person-job fit perspective. Journal of Business Inquiry: Research, Education \& Application, 7, 68-78.

Shamir, B., House, R. J., \& Arthur, M. B. (1993). The motivational effects of charismatic leadership: A self-concept based theory. Organization Science, 4, 577-594.

Sheep, M. (2006). Nurturing the whole person: The ethics of workplace spirituality in a society of organizations. Journal of Business Ethics, 66, 357-375.

Sheldon, K. M., \& Elliott, A. J. (1998). Not all personal goals are personal: Computing autonomous and controlled reasons for goals as predictors of effort and attainment. Personality and Social Psychology Bulletin, 24, 546-557.

Sibbet, D. (1997). 75 years of management ideas and practice 1922-1997. Harvard Business Review, $75(5), 2-12$.

Sparks, J. R., \& Schenk, J. A. (2001). Explaining the effects of transformational leadership: an investigation of the effects of higher-order motives in multilevel marketing organizations. Journal of Organizational Behavior, 22, 849-869.

Tabachnick, B. G., \& Fidell, L. S. (2006). Using Multivariate Statistics. Boston, MA: Allyn and Bacon.

Taylor, F. W. (1947). Scientific management. New York, NY: Harper and Row.

Terborg, J. R. (1976). The Motivational Components of Goal-Setting. Journal of Applied Psychology, 61(5), 613-622.

Thompson, W. D. (2000). Can you train people to be spiritual? Training \& Development, 54(12), 18.

Tischler, L., Biberman, J., \& Altman, Y. (2007). A model for researching about spirituality in organizations. Business Renaissance Quarterly, 2, 23-39.

van Tonder, C. L., \& Ramdass, P. (2009). A spirited workplace: Employee perspectives on the meaning of workplace spirituality. South African Journal of Human Resource Management, 7, 230-241.

Waddock, S. A., \& Graves, S. B. (1997). The corporate social performance-financial performance link. Strategic Management Journal, 18, 303-319.

Wrzesniewski, A., McCauley, C. R., Rozin, P., \& Schwartz, B. (1997). Jobs, careers, and callings:

People's relations to their work. Journal of Research in Personality, 31, 21-33. 